\title{
The Need for Customized Academic Dresses for the Tertiary Institutions in Ghana: A Study of Kumasi Technical University Community
}

\author{
Peggy Maansah Ankai Howard ${ }^{1}$, Michael Ato Essuman ${ }^{1}$, Thomas Obeng Asare ${ }^{1}$, \\ Kweku Bedu Simpson", * \\ ${ }^{1}$ Department of Fashion Design and Textile Studies, Kumasi Technical University, Kumasi, Ghana \\ ${ }^{2}$ Department of Architectural Drafting, Accra Technical Training Centre, Accra, Ghana
}

Email address:

kwekusimpson48@gmail.com (K. B. Simpson)

${ }^{*}$ Corresponding author

\section{To cite this article:}

Peggy Maansah Ankai Howard, Michael Ato Essuman, Thomas Obeng Asare, Kweku Bedu Simpson. The Need for Customized Academic Dresses for the Tertiary Institutions in Ghana: A Study of Kumasi Technical University Community. American Journal of Art and Design. Vol. 4, No. 3, 2019, pp. 31-40. doi: 10.11648/j.ajad.20190403.12

Received: September 10, 2019; Accepted: October 4, 2019; Published: October 25, 2019

\begin{abstract}
Issues have been raised about the identity challenges that seem to have characterized most tertiary institutions in Ghana especially the Technical Universities as regards the academic gown usage during academic ceremonies. The usual practice is that Institutions who do not own the gowns hire from the traditional universities whose aims and philosophies are often at variance with them and in effect results in identity crisis. The aim of this paper was to investigate the issues concerning how gowns are used in the study area and the design expectations for befitting customized gowns. To do that descriptive research with cross sectional survey was undertaken in the study area using convenience and simple random sampling techniques and data were collected from 400 respondents. The findings were that most respondents recognised the existence of the issues pertinent to the use of the academic ensembles that amount to identity challenges and admitted that these issues need to be addressed by acquiring befitting customised academic dresses. Additionally, respondents were almost unanimously in favour of the various gown components designed to portray the philosophies and traditions of the institution and its faculties, be of good quality material, exquisitely sewn and being durable. Respondents indicated the need for deans of faculties to have special academic costumes specific to their status and positions and in all, they were of the view that gowns must have an indigenous traditional touch. It is thus recommended that all academic institutions in Ghana should acquire their own academic dresses which are in tune with their philosophies and traditions and capable of visibly differentiating them from their sister institutions. This outcome will help policy makers in their quest for the appropriate academic robes for their various institutions and faculties and also whip up interest for acquiring befitting academic robes. It will as well add to the body of knowledge for the use by the academia and other interested researchers.
\end{abstract}

Keywords: Identity Crisis, Academic Dress, Tertiary Institutions, Academic Gown Issues, Design Expectations, Ghana

\section{Introduction}

\subsection{Background}

Academic dresses are special robes mostly worn on special occasions on the academic calendars of the institutions. They were adapted from both secular and clerical garments of the time, and their use started way back in the middle ages where scholars at the earliest English and European universities wore garments of wool and fur to keep their heads warm in their poorly heated buildings. [1] The practice soon became associated with students in the 1300s and was the standard academic dress for the universities of Oxford and Cambridge. The use of the academicals were discontinued during the $16^{\text {th }}$ and $17^{\text {th }}$ centuries in most part of Europe due to religious and political upheavals at the time except in some countries where only professors used them. [2] There were other countries which maintained only an aspect of the attire like 
the insignia such as doctoral sword, hats, or rings. However, the full academic gown usage was restricted to Great Britain and Iberia alone and in the advent of the Colonial expansion of countries, the use of the academic costumes caught up with many others. Detailed regulations were introduced in the use of the academic garb in the $16^{\text {th }}$ centuries and Oxford and Cambridge universities took the initiative of prescribing a specific system of academic dress. In effect, most British universities including universities in Ireland modelled their academic dress systems on the Oxford-Cambridge styles. [3, 26]

Columbia College which was established in 1754 in New York adopted the regalia after which more colleges in America joined in the $19^{\text {th }}$ centuries. Academic gown usage has been widely accepted among the American academic institutions though it disappeared after a century of its adoption some years back. [4] The use of the gown assumed an upward surge after the end of the World War II when the number of universities at the time increased enabling the Americans with the modest means to enroll which hitherto was not so. This was because "Many of them wanted to adopt the outward signs of their University connections of which the academic gown was one of them". [5] These special costumes used to be the preserve of the academic institutions of higher learning but recently even preschool /kindergarten graduands don them to signify their rite of passage to their next educational level.

In the 1950s, Ghana started using the gown when university of Ghana was affiliated to the University of London. [6] Like the foreign academicals, the academic dresses worn by the traditional universities in Ghana are also distinguished in respect of the level of degree or rank (i.e. undergraduates, bachelors, masters, doctorates, principal officers and the like). These distinctions more often lie in the various elements of the gown with the designs varying from one academic institution to the other depending on their philosophies. Nonetheless, only few institutions in Ghana own the gowns and therefore most hire them from the older institutions at a very high cost. [7] This has brought in its wake the issue of identity crisis where students of a particular institution are forced to be identified with another institutions' philosophy and identity thus defeating the very essence of the ensemble. Academic gowns are the official outfits identifying and differentiating one academic institution from another; thus, their designs in Ghana must have relevance to Ghanaian culture and identity visually. [8] The author argues that academic costumes must be designed to reflect the aims and philosophies of the institutions for which they are meant. [8] This stands to reason that for the purpose of proper identity and uniqueness, academic institutions must acquire gowns of their own capable of portraying loudly their unique identities for better recognition.

The gown is made of items of clothing consisting of gown, a hood / stole, and the hat and all its elements depicts the status and achievement of the wearer. Additionally, the degree levels are in consonance with the varied academic dresses worn. There are differences between different types of academicals: the bachelor gown, the masters' gown and the doctor's gown. [3]

The design of the headgear (mortarboard) may depend on the level of academic achievement and to some extent on the individual's academic institution's specification. Whilst the mortarboard cap (trencher) is traditionally used with academic regalia as a standard for all levels of degree, velvet tam (bonnet) is for the award of a doctoral degree. [9, 15] However, not all academic institutions use headgear except the principal officers. For instance in the University of Sterling, it's only the Chancellor, the Principal and ViceChancellor who wear the headwear on special occasions such as conferment of degrees and other academic distinctions. [10]

The hood being the most colourful and distinctive element of academic garb, used to be worn by monks in England to keep their heads warm. [11] Presently, the hood displays the institution's colour where the wearers received their degrees and denotes the academic field of the wearer. $[3,11,12]$ In the United States, the hood's colouring and size represents the type and subject of degree earned as well as the institution from which it was awarded. [4]

In respect of the robes, the bachelor robe has pointed sleeves and is worn closed while the master's one has oblong sleeve. Even though the base of the sleeves hangs down in a typical manner, it is square cut at the rear part of the oblong shape. The front part has an arc cut away and there is a slit for the wrist opening but the rest of the arc is closed. It is designed to be worn either open or closed. [12] Doctoral robes are typically black but may be in the colours specified by the awarding Institution. Generally, the robes are similar to that of the bachelor's graduate with the addition of the three velvet bands on the sleeves and velvet- facing running down the front of the gown. The robes have bell-sleeve of the bachelor's gown with exposed necktie or cravat when closed. [13] Other types have a cape like form that is designed to be worn closed. [14]

Material suitable for the gowns is dependent on the prevailing climate and therefore may differ from very light to very heavy, provided the chosen material, colour, and pattern are in accordance with the prescribed rules. Usually, the colour black is recommended. Some of the materials for the academic gown may be cotton poplin, broadcloth, rayon or silk. [12] And others like the satin, cotton and worsted could also be used. For the caps similar fabrics just stated could be used except for only doctorate where velvet is usually the material for the cap. [13]

Literature on foreign academic gowns indicates that colours play a vital role in the design of the academicals and in the Americas and Europe, standardised colours earmarked for faculties and institutions are included in the design of the academic dress. Such codified colours are associated with different academic disciplines and levels as well as the institutions, which enable easy identification and recognition. $[3,11,12]$ Records show that London University appears to be the first British university to have invented the system of 
faculty colours in the $19^{\text {th }}$ centuries which eventually persuaded many new and existing universities around the world to adopt a faculty colour system for their academic dress in whole or in part. [9] On the local front, some institutions use colours or different colours of kente strips to distinguish one academic level from the other. For instance, Kwame Nkrumah University of Science and technology (KNUST) uses the collegiate system to differentiate the bachelor gowns by colour but employs same design system for equivalent masters' degrees gowns. University of Ghana on the other hand, uses equivalent degree system to categorise the gowns for bachelors, masters and doctorate degree graduands and holders by different kente panels and colour of robes, [6] whereas University of Education uses different colours to indicate academic departments or faculties. [15]

The use of the academic garb adds colour, spectacle and a sense of occasion to conferring ceremonies and also serves as symbolism to the continual role of universities as centers for the advancement of learning. [3] Essentially, all universities abroad adopt their own system of dress to distinguish their students and degrees, a powerful expression of the identity of the University and the shared history and tradition of its institutions. [3]

Dress is "the act of choosing how and with what items or processes to construct personal appearance". [16] It confers identity on the user/individual in that it provides a means of communication to positions within social structures such as kinship, economic religious and political activities. Dress providing a means of communication means that wearers /individuals establish identities and selves and attribute identities to the others. [17] According to, [18] "identity and dress are intimately linked' and that 'clothes displays, express and shapes identity imbuing with it a directly material reality". The author notes that clothing is a linguistic code- a means whereby people send messages about themselves. Therefore academic dress as a type of dress or clothing should be able to announce the status and achievement of the wearer.

Kumasi Technical University, just like the many academic institutions in Ghana also rent the ensembles during graduation ceremonies at an exorbitant cost from the older institutions whose philosophies and aims are entirely at variance with that of the University. This creates identity crisis when those gowns are used. [7] The authors found that $56.3 \%$ favoured the continued usage of the academic dress for academic ceremonies, and most respondents $79.2 \%$ and $81.1 \%$ respectively claimed that both the institution's colours and the faculty colours must be included in the design of the gowns for uniqueness and recognition. The authors therefore recommended that to forestall the situation whereby graduands of the institution are wrongly identified, it was imperative that customized academic dresses be designed for academic ceremonies. These should reflect the Faculty and the Institution's colours, as well as incorporate the indigenous traditional designs relevant to the aims and philosophies of the institution, as practised in some older universities in Ghana. [7] In the Kumasi Technical University, few gowns have been made for the HND graduands however, the details of the design and its corresponding philosophies are undisclosed probably because it has not been thought through yet. [7] Again the deans who are the heads of the faculties most often are seen identified in the robes meant for KNUST PhD graduands and holders, a situation which is very unfortunate unlike what pertains in Europe and the Americas. Foreign universities have special academic costumes for certain of their officers to be won on ceremonial occasions. [9] There is thus the need to design a befitting academic robe for the deans and other members of faculties for better identification and uniqueness. This should distinguish visibly their institution from the others as well as one faculty of the institution from the other. This design should reflect the Faculties' and the Institution's colours, as well as incorporate the indigenous traditional designs relevant to the aims and philosophies of the institution.

The essence of this paper was to investigate the issues surrounding the use of academic gowns in the Technical University and the design expectations for a customised and befitting academic garb. It is believed that the result will help policy makers make an informed prescription of the appropriate gowns for the various faculties and their deans and also whip up interest for acquiring befitting academic gowns. It will also add to the body of knowledge for the use of the academia and other interested researchers.

\subsection{Objectives}

In order to undertake the study, the following objectives were used:

i. To investigate the issues surrounding academic dress in the Technical University

ii. To determine the design expectations of the would-be users in respect of the proposed gown.

\subsection{Hypothesis}

The hypothesis were as follows:

i. There is no statistical difference among the faculty members as regards the issues bordering on academic gown usage.

ii. There is no statistical difference among the faculty members as regards the design expectations of the would-be users in respect of the proposed gown.

\subsection{Conceptual Framework}

In order to obtain a befitting academic dress, the dress in its entirety should be designed to be responsive to the aims and philosophies of the institution and the faculties for which the dress is meant. Essentially, the hood should be able to display the institution and the faculty colours and the academic field of the wearer as well. The headgear (mortarboard), should have its tassel colour indicating the wearer's area of study. The robe should be of appropriate colour. The others such as logos for the institution and faculties should be designed to represent the aims and 
philosophies of both the institution and the faculties and must be embossed on the dress. The academic dress on the whole should have an African touch by incorporating indigenous traditional designs for example appropriate kente and adinkra designs for distinguishing different degree levels and positions, be made of quality fabrics, exquisitely sewn for aesthetic and durability purposes (see Figure 1).

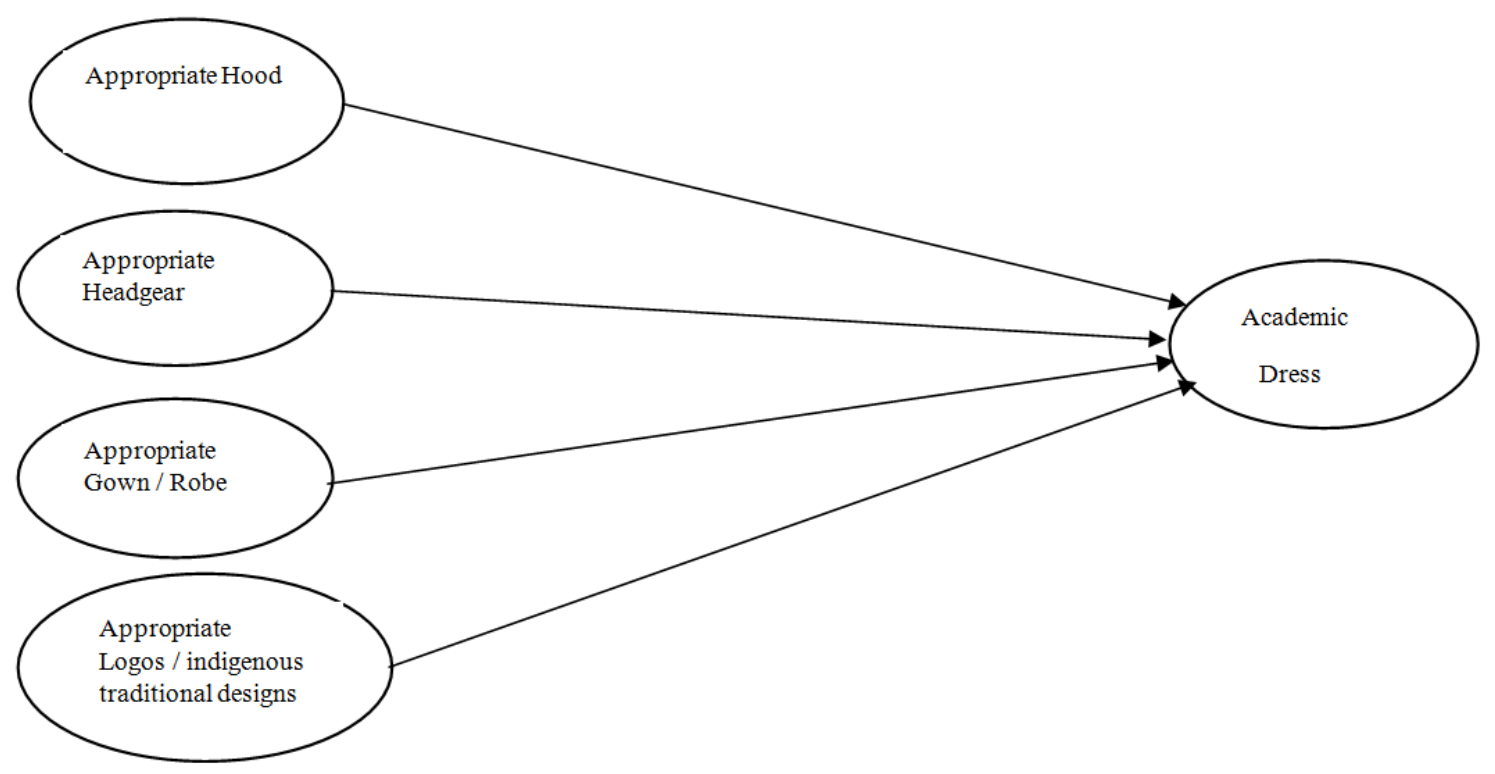

Figure 1. Conceptual Framework.

\section{Methodology}

\subsection{The Study Area}

Kumasi Technical University is a public tertiary institution in the Ashanti Region of Ghana, one of the Polytechnics in Ghana which was converted into a Technical University in 2017. It is located at the heart of Kumasi, the capital city of the Ashanti Region of Ghana. It was founded in 1954. It consist of seven faculties, two school and one institutes namely; School of Business, Built and Natural Environment, Engineering and Technology, Applied Sciences and Technology, Creative Arts and Technology, Health Sciences, Entrepreneurship and Enterprise Development, Institute of Distance and Continuing Education and School of Graduate Studies, Research and Innovation. The university awards certificates for Intermediate, Advance, Technician, HND and Bachelor programmes. Currently, there are about 273 full time lecturers, 9,056 students and 371 central administrative staff. Every year, matriculations and graduations are held for the newly admitted students and those who have successfully completed their programmes of study respectively.

\subsection{Research Design}

The study basically employed descriptive research [19] and applied cross sectional survey to collect data in order to make inferences about the population at that point in time. [20]

\subsection{Sampling Techniques}

Convenience sampling [21] and simple random sampling techniques $[22,23]$ were employed in collecting data from
400 Technical University community members in Kumasi Technical University.

\subsection{Instrument and Data Collection Procedure}

The study's primary data was collected using questionnaire administered by the researchers at the Kumasi Technical University. The questionnaire data covered

(1) Bio data/Personal records (e.g. gender, age, current educational level, name of institution and programme offered),

(2) Issues surrounding academic dress in the Technical University and

(3) Design expectations of the would-be users in respect of the proposed gown.

Appropriate Likert scale types were employed to gather the data. For example, 5-points Likert scale type ranging from $(1=$ strongly disagree to $5=$ strongly agree) were used to determine the academic gown issues and the design expectations of the proposed gown. The questionnaires also had a preamble spelling out the rationale for the study as well as a statement assuring respondents of the necessary confidentiality and anonymity deserved. [24] Both content and face validity procedures were employed to ensure the validity of the instrument. To determine the instrument's reliability, the questionnaire was pretested through a pilot study. Respondents for the full-scale study were either in their offices or from examination rooms when data were collected. In order for the respondents to make informed decisions to contribute meaningfully to the study, a background underlying academic gowns was provided. Though the instrument 
was taking through the test of validity and reliability, opportunity was offered for clarification and explanations to the respondents who needed help. Respondents used between 20 and 25 minutes to complete one questionnaire. Data were collected in May 2019.

\subsection{Data Analysis}

The survey data was analyzed using descriptive statistics (i.e. frequency, mean, standard deviation). Inferential statistical tool such as Kruskal -Wallis $\mathrm{H}$ test helped to establish the statistical differences among the various faculty members as to the various issues currently surrounding the use of the academic costumes and the need to acquire a customised one and moreover, the design expectations of the new ones using 'p' value of 0.001 . [25]

\section{Results}

The results of the study covers the characteristics of the respondents, issues about the academic gown usage in the university community and the design expectations of the respondents in respect of the proposed academic gowns for the Technical University.

\subsection{Characteristics of the Respondents}

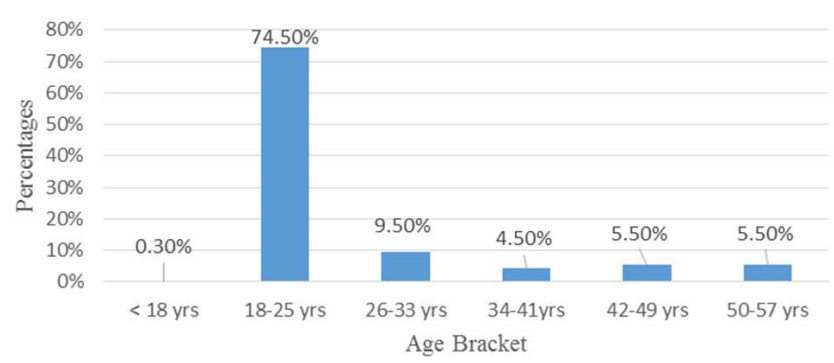

Figure 2. Respondents'age bracket.

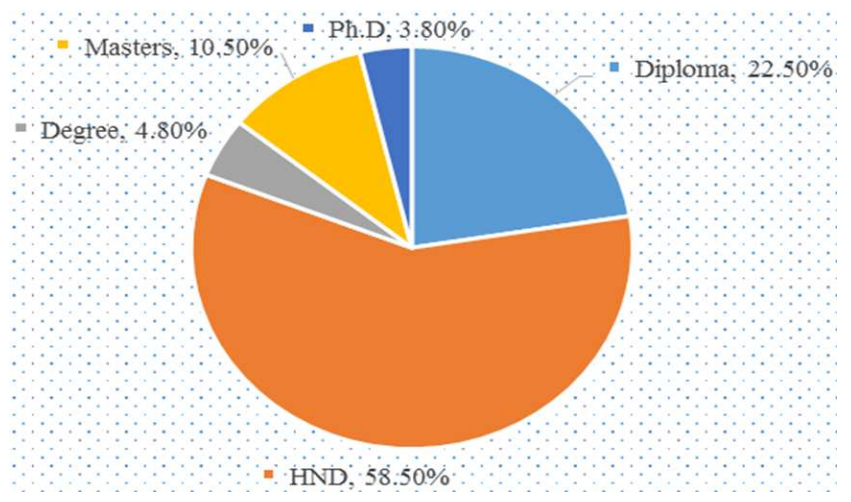

Figure 3. Respondents' level of education.

400 respondents were contacted through convenience and simple random sampling and all questionnaires were retrieved. The questionnaire items had a reliability value of 0.859 implying an excellent reliability of the questionnaire items [25]. Respondents were made up of male (42.8\%) and female (57.2\%). 74.8\% were aged between 18 and 25 years, $0.3 \%$ below 18 years with the rest more than 25 years (Figure 2). Majority $(81 \%)$ were either HND or Advance Diploma students with the rest (19\%) catering for Bachelor, Masters and Ph.D. holders (Figure 3). Most (80\%) of the respondents were students, $15.5 \%$ lecturers (ranging from assistant lecturers to professors) whereas the remaining were administrators (Figure 4). More (25.3\%) of the respondents were drawn from the School of Business, followed by $25 \%$ Applied Science and Technology, 23.8\% Engineering and Technology, 3\% Administration and very few from Built and Natural Resources. This was because Built were not present at the time of data collection and only 2 of the lecturers took part in the study (Figure 5).

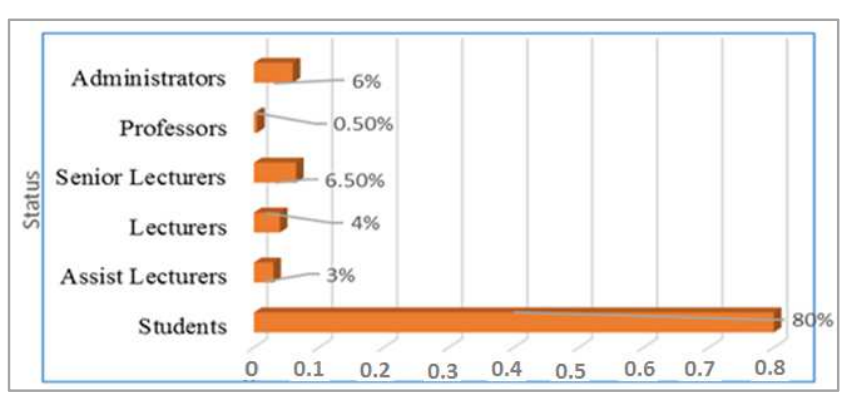

Figure 4. Respondents'status/position.

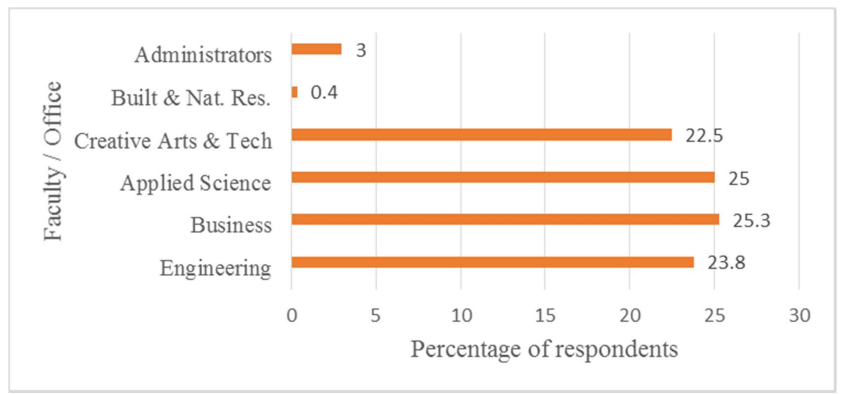

Figure 5. Respondents'faculty/office.

\subsection{Issues About the Academic Gown Usage}

In Table 1, respondents were presented with a list of statements describing the issues about the academic gown usage at the Technical University. This was done to verify how they perceived the situation to be and for which a befitting gown be designed. The result revealed that higher number of respondents either 'agreed' or 'strongly agreed' to all the issues raised in the table about the stated subject. More respondents were in favour of the statements that 'wearing academic gown belonging to another institution can result in wrong identification leading to identity crises and that 'it was important for an institution to be properly identified with its own academic gown' and therefore a 'befitting academic gown is necessary for the university and the faculties'. 
Table 1. Issues about the university's academic gown usage.

\begin{tabular}{|c|c|c|c|c|c|}
\hline \multirow{2}{*}{ Issues } & \multicolumn{5}{|c|}{ Level of Agreement } \\
\hline & No & Min & Max & Mean & SD \\
\hline I am happy when I see graduands in academic gowns. & 400 & 1 & 5 & 4.53 & 0.671 \\
\hline Graduands in academic gowns look attractive. & 400 & 2 & 5 & 4.51 & 0.557 \\
\hline I am unhappy to see graduands robed in other institution's academic dress. & 400 & 1 & 5 & 4.44 & 1.095 \\
\hline I am not happy to see faculty deans robed in hired academic costumes. & 400 & 1 & 5 & 4.41 & 0.993 \\
\hline Academic gowns do not clearly show faculty distinctions. & 400 & 1 & 5 & 4.35 & 1.039 \\
\hline Academic gowns do not clearly show institutional distinctions. & 400 & 1 & 5 & 4.37 & 0.968 \\
\hline Academic gowns do not show the colour of my institution and that of my faculty. & 400 & 1 & 5 & 4.31 & 1.075 \\
\hline $\begin{array}{l}\text { Academic gowns are not designed based on the aims and philosophy of the university and the } \\
\text { faculties. }\end{array}$ & 400 & 1 & 5 & 4.32 & 1.053 \\
\hline Deans of faculties do not wear befitting academic robes specific to their respective faculties. & 400 & 1 & 5 & 4.33 & 0.878 \\
\hline $\begin{array}{l}\text { Wearing academic gown belonging to another institution can result in wrong identification leading } \\
\text { to identity crisis. }\end{array}$ & 400 & 1 & 5 & 4.6 & 0.778 \\
\hline It important for an institution to be properly identified with its own academic gown. & 400 & 1 & 5 & 4.73 & 0.527 \\
\hline
\end{tabular}

Based on the result in Table 1, there was the need to find out whether there were statistical differences among the faculty members as regards the issues bordering on academic gown usage. In Table 2, the Kruskal Wallis H test depicts that significant differences existed in the ratings of the faculty respondents concerning the academic gown issues except, 'I am unhappy to see graduands robed in other institution's academic dress' $\left(\chi^{2}=11.816, \mathrm{df}=5 ; \mathrm{p}<0.001\right)$, 'academic gowns are not designed based on the aims and philosophy of the university and the faculties' $\left(\chi^{2}=16.869, \mathrm{df}=5 ; \mathrm{p}>0.001\right)$ and 'wearing academic gown belonging to another institution can result in wrong identification leading to identity crisis' $\left(\chi^{2}=19.354, \mathrm{df}=5 ; \mathrm{p}>0.001\right)$ where the opinions were similar.

Table 2. Kruskal Wallis $H$ Test result for statistical differences among the faculties regarding the gown issues.

\begin{tabular}{|c|c|c|c|}
\hline \multirow{2}{*}{ Issues } & \multicolumn{3}{|l|}{ Test Statistics ${ }^{\mathrm{a}, \mathrm{b}}$} \\
\hline & Chi-Square $\left(\chi^{2}\right)$ & df & Significance \\
\hline I am happy when I see graduands in academic gowns (dresses) & 49.447 & 5 & 0.000 \\
\hline Graduands in academic gowns look attractive & 53.029 & 5 & 0.000 \\
\hline I am unhappy to see graduands robed in other institution's academic dress. & 11.816 & 5 & 0.037 \\
\hline I am not happy to see faculty deans robed in a hired academic costumes & 34.797 & 5 & 0.000 \\
\hline Academic gowns do not clearly show faculty distinguish & 26.161 & 5 & 0.000 \\
\hline Academic gowns do not clearly show institutional distinctions & 49.236 & 5 & 0.000 \\
\hline Academic gowns do not show the colour of my institution and that of my faculty & 33.487 & 5 & 0.000 \\
\hline Academic gowns are not designed based on the aims and philosophy of the university and the faculties & 16.869 & 5 & 0.005 \\
\hline Deans of faculties do not wear befitting academic robes specific to their respective faculties. & 32.769 & 5 & 0.000 \\
\hline $\begin{array}{l}\text { Wearing academic gown belonging to another institution can result in wrong identification leading to } \\
\text { identity crisis }\end{array}$ & 19.354 & 5 & 0.002 \\
\hline It important for an institution to be properly identified with its own academic gown & 66.610 & 5 & 0.000 \\
\hline $\begin{array}{l}\text { A befitting academic gown is necessary for the university and the faculties } \\
\text { Difference is significant at } p=0.001\end{array}$ & 41.288 & 5 & 0.000 \\
\hline
\end{tabular}

\subsection{Design Expectations of the Proposed Academic Gowns for the Technical University}

It was very important to investigate the design expectations of the university community since knowing these could help in producing befitting gowns capable of effectively identifying the wearers. The components for which respondents shared their opinions as to how best they should be designed and produced included the hood, gown, headgear and the deans' costumes. In order to seek the views of the respondents regarding the design of customised academic gowns, they were requested to indicate their degree of agreement or otherwise to the list of design expectations/requirements presented to them in a table. The result illustrated in Table 3 showed that once again respondents were almost unanimous in support of the design expectations of the proposed academic costumes for the University. More especially, 'deans' costumes must be exquisitely sewn to befit their status and must be durable, quality materials be used to design the gowns to ensure durability and gown should be properly sewn, 'the institution's and faculty logos should be included in the academic dress design and the logos used should reflect the aims and philosophies of the institution and the faculties among others.

Following the result in Table 3, the study wanted to verify whether there were statistical differences among the faculty members as regards the design expectations of the would-be users in respect of the proposed gown. In consequent of that the test statistics presented in Table 4 indicated that there were significant differences in the ratings of the faculty respondents as regards the design expectations. However, 'the logos should reflect the aims and philosophies of the institution and the 
faculties' $\left(\chi^{2}=18.359, \mathrm{df}=5 ; \mathrm{p}>0.001\right)$, 'the head gear should be of mortar board and with a tassel whose colour is in line with the wearer's area of study' $\left(\chi^{2}=16.682, \mathrm{df}=5 ; \mathrm{p}>0.001\right)$ as well as 'the costumes must be exquisitely sewn to befit their status' $\left(\chi^{2}=9.120, \mathrm{df}=5 ; \mathrm{p}>0.001\right)$, recorded no significant statistical difference among the respondents, meaning the variations in their responses are negligible.

Table 3. Design expectations / requirements for the various gown components.

\begin{tabular}{|c|c|c|c|c|c|}
\hline \multirow{2}{*}{ Expectations } & \multicolumn{5}{|c|}{ Level of Agreement } \\
\hline & No & Min & Max & Mean & SD \\
\hline \multicolumn{6}{|l|}{ Hood } \\
\hline Hood should be designed with the appropriate colours & 400 & 3 & 5 & 4.49 & 0.557 \\
\hline Hood's colours should be designed to portray the institution's colour and the faculty colour & 400 & 1 & 5 & 4.57 & 0.570 \\
\hline The hood should provide a means of identifying the degrees held by the wearer & 400 & 1 & 5 & 4.37 & 0.791 \\
\hline It should be beautifully sewn and must be durable & 400 & 1 & 5 & 4.56 & 0.614 \\
\hline \multicolumn{6}{|l|}{ Gown (robe) } \\
\hline The gown should be in an appropriate colour easy to be handled and maintained. & 400 & 3 & 5 & 4.50 & 0.539 \\
\hline Gowns must have appropriate sleeves & 400 & 2 & 5 & 4.41 & 0.619 \\
\hline The gown must have a touch of indigenous traditional designs & 400 & 1 & 5 & 4.34 & 0.896 \\
\hline The institution's and faculty logos should be included in the academic dress design. & 400 & 2 & 5 & 4.63 & 0.596 \\
\hline The logos should reflect the aims and philosophies of the institution and the faculties. & 400 & 1 & 5 & 4.63 & 0.651 \\
\hline The gown should be worn over a formal undergarment. & 400 & 1 & 5 & 4.31 & 0.952 \\
\hline The front panel of the gown should be beautifully designed with appropriate kente strips. & 400 & 1 & 5 & 4.43 & 0.876 \\
\hline Gowns should be designed to be different at each degree level & 400 & 1 & 5 & 4.48 & 0.849 \\
\hline Quality materials should be used to design the gowns to ensure durability. & 400 & 1 & 5 & 4.69 & 0.542 \\
\hline The academic gown should be properly sewn. & 400 & 3 & 5 & 4.65 & 0.498 \\
\hline \multicolumn{6}{|l|}{ Headgear } \\
\hline $\begin{array}{l}\text { The headgear should be of mortarboard and with a tassel whose colour is in line with the } \\
\text { wearer's area of study. }\end{array}$ & 400 & 1 & 5 & 4.35 & 0.780 \\
\hline It should be properly sewn and must be durable & 400 & 3 & 5 & 4.56 & 0.508 \\
\hline \multicolumn{6}{|l|}{ Deans' costumes } \\
\hline $\begin{array}{l}\text { Deans must wear appropriate academic costumes specific to their respective faculties and } \\
\text { positions. }\end{array}$ & 400 & 2 & 5 & 4.60 & 0.602 \\
\hline The costumes must be exquisitely sewn to befit their status & 400 & 3 & 5 & 4.72 & 0.481 \\
\hline It must be durable. & 400 & 3 & 5 & 4.69 & 0.475 \\
\hline
\end{tabular}

Table 4. Kruskal Wallis H Test result for statistical differences among the faculties regarding the design expectations.

\begin{tabular}{|c|c|c|c|}
\hline \multirow{2}{*}{ Design Expectations } & \multicolumn{3}{|l|}{ Test Statistics ${ }^{\mathrm{a}, \mathrm{b}}$} \\
\hline & Chi-Square $\left(\chi^{2)}\right.$ & Df & Significance \\
\hline \multicolumn{4}{|l|}{ Hood } \\
\hline Hood should be designed with the appropriate colours & 48.983 & 5 & 0.000 \\
\hline Hood's colours should be designed to portray the institution's colour and the faculty colour & 58.350 & 5 & 0.000 \\
\hline The hood should provide a means of identifying the degrees held by the wearer & 34.851 & 5 & 0.000 \\
\hline It should be beautifully sewn and must be durable & 53.851 & 5 & 0.000 \\
\hline \multicolumn{4}{|l|}{ Gown } \\
\hline The academic gown should be front open such that the undergarment could be visible. & 23.256 & 5 & 0.000 \\
\hline The gown should be in an appropriate colour easy to be handled and maintained. & 43.754 & 5 & 0.000 \\
\hline Gowns must have appropriate sleeves & 44.273 & 5 & 0.000 \\
\hline The gown must have a touch of indigenous traditional designs & 19.796 & 5 & 0.001 \\
\hline The institution's and faculty logos should be included in the academic dress design. & 28.213 & 5 & 0.000 \\
\hline The logos should reflect the aims and philosophies of the institution and the faculties. & 18.359 & 5 & 0.003 \\
\hline The gown should be worn over a formal undergarment. & 34.359 & 5 & 0.000 \\
\hline The front panel of the gown should be beautifully designed with appropriate kente strips. & 41.648 & 5 & 0.000 \\
\hline Gowns should be designed to be different at each degree level & 33.864 & 5 & 0.000 \\
\hline The gown should be able to announce the wearer's achievement in their area of study. & 27.727 & 5 & 0.000 \\
\hline Quality materials should be used to design the gowns to ensure durability. & 33.053 & 5 & 0.000 \\
\hline The academic gown should be properly sewn. & 46.099 & 5 & 0.000 \\
\hline \multicolumn{4}{|l|}{ Headgear } \\
\hline $\begin{array}{l}\text { The headgear should be of mortarboard and with a tassel whose colour is in line with the wearer's area of } \\
\text { study. }\end{array}$ & 16.682 & 5 & 0.005 \\
\hline It should be properly sewn and must be durable & 27.958 & 5 & 0.000 \\
\hline \multicolumn{4}{|l|}{ Deans' Costumes } \\
\hline Deans must wear appropriate academic costumes specific to their respective faculties and positions. & 36.913 & 5 & 0.000 \\
\hline The costumes must be exquisitely sewn to befit their status & 9.120 & 5 & 0.104 \\
\hline It must be durable. & 43.772 & 5 & 0.000 \\
\hline Difference in rating is significant at $\mathrm{p}=0.001$ & & & \\
\hline
\end{tabular}




\section{Discussions}

The findings to the issues characterising how academic dresses are used for academic ceremonies in the Kumasi Technical University suggest an urgent call for a paradigm shift in academic gown usage since respondents are not pleased with the issues surrounding it. For instance, majority of the respondents were of the opinion that wearing academic dress of another institution is not appropriate and hence amount to identity crisis, and it is important for every academic institution to be properly identified in their own gown as well as a befitting gown being necessary for the university (Table 1). It has been argued that by putting on a dress, an identity is conferred on you the wearer and this provides a means of communication that link wearers' identity and self to others. [17] In like manner, [18] opined that 'identity and dress are intimately linked' and that 'clothes display, express and shape identity making it real in material terms. With this, it is thus in place that the right dresses are worn for the right occasion so that the right interpretation could be given by others. Academic dress as special ensembles for academic ceremonies when donned should be able to express the right message about the wearer to the observers for the right recognition. In situations where inappropriate dresses are won because of traditional and philosophical differences between the institutions from which the gowns are hired and the institution in need, culminating in identity challenges should be stopped. A time has come for tertiary institutions to be effectively identified and recognised in their own customised costumes on ceremonial occasions since academic gowns are the official outfits identifying and differentiating one academic institution from another. [8]

The findings also showed the design expectations of the university community as regards the proposed academic gowns. Exemplary, with the hood, respondents expect it to be designed with appropriate colours representing the institution and the faculty colours, and that it should provide means of identifying the degrees held by the wearer, beautifully sewn and must be durable (Table 3). Undeniably, the hood has been the most colourful and distinctive element of academic garb functioning as the main means of displaying the institution's colour from where wearers obtained their degree as well as depicting the academic field of the wearer. $[3,12]$ Therefore, if respondents are opting for that then it will be good for proper identification and recognition.

The robe/gown being designed to be front open in order to reveal the formal undergarment when worn must have the appropriate sleeves, with appropriate logos reflecting the traditions, aims and philosophies of the faculties and that of the institution. It must be beautifully sewn with quality materials with front panel made of appropriate kente strips and designed differently at different academic levels (Table 3 ) for proper identification and recognition.

This practice is found in some institutions in and outside Ghana. Example, University of Ghana uses equivalent degree system for the various academic levels by different kente panels and colour of robes [6] whereas; University of Education uses different colours to indicate academic departments or faculties. [15] Similarly, KNUST uses the collegiate system to differentiate the bachelor gowns by colour but employs same design system for equivalent masters' degrees gowns. So, it will not be out of place for the respondents to support that.

Most respondents' were in favour of the statements describing the design expectations of the headwear. Undoubtedly, the mortarboard cap (trencher) has in most cases been the standard cap that accompanies the academic dress for all levels of degree, except $\mathrm{Ph}$. D. In some cases, the coloured tassel connotes the wearers' area of study. [10] It is thus in place that the university community support the proposal in Table 3.

Similarly, respondents massively supported the statements in Table 3 as regards the deans' costumes. Internationally and locally, all academic institutions have their officers who have their prescribed gowns to be fit their status as found in the traditional universities in Ghana $[6,15]$ and the universities abroad. [9] Befitting and customised academic regalia is supposed to be responsive to the traditions and philosophies of the academic institutions, able to make wearers unique and recognisable and providing the linguistic code by which messages about the wearer could be communicated to the observer. [9] Therefore, it is apt that Kumasi Technical University authority will provide customised gowns for the deans in the various faculties.

\section{Conclusion}

All in all, this paper has been able to investigate the issues surrounding academic gown usage in the Kumasi Technical University and the design expectations of the wearers and would-be-wearers for a befitting academic dress. The study first and foremost set the objectives underlying the topic and subsequently searched through extensive literature concerning the history, significance and the design of academic gowns and these were noted. The study then employed descriptive research through cross sectional survey using convenience and simple random sampling techniques to administer 400 questionnaires in the study area. The same number of questionnaires were retrieved because the researchers had to make sure that everybody completed and submitted the given questionnaires. All questionnaires were analysed and the reliability value of the items was found to be acceptable.

The findings were that many respondents appreciated the numerous issues surrounding academic gown usage in the university which amounted to identity challenges and based on that indicated the need for a befitting and customised academicals that could effectively identify the deans and faculty members of the various faculties in the university. For a befitting academic garb to be produced, respondents were almost unanimously in favour of gowns whose elements are designed taken into consideration the aims and the 
philosophies of the institution and its faculties so that when the dresses are donned they could send the right messages about the wearers to the observers without any cause for confusion.

The dresses are to be well designed with the appropriate fabrics and a touch of indigenous traditional symbols and designs.

There is no gainsaying of the fact that dress and identity go hand in hand, and if these very important regalia are worn to depict the traditions and philosophies of another institution then it may mean that the institution in question has not come of age to showcase what it stands for. Arguably, as wearers often don the academicals with pride and hope believing that such colourful and important attire signifies a lifelong intellectual flame for illuminating society, the dress must fully represent their identity. We are unable to know whether it is because of lack of funds, or the authorities do not see that as priority or it may also be that they have not thought through the design yet. Whatever the case may be, it is imperative that there is paradigm shift in the gown acquisition that is, moving from hiring to permanent acquisition as early as possible. Uniqueness of academic costumes for higher academic institutions such as Kumasi Technical University must not be sacrificed on the altar of 'no money.' After all wearers will pay for its usage. It is believed that with the results obtained, authorities of the university will find it crucial to facilitate the acquisition of the gowns for the institution to forestall identity crisis.

With these findings, the next important thing to do is to look at designing and producing the gowns considering the various design expectations and all others. Again the various logos and the appropriate faculty colours could be worked on.

Though findings favourably represent the views of the Technical University community, its generalizability may not be wholly extended to the other universities that may be suffering similar fate. In spite of that, this study could provide a fertile ground for such universities to make informed decisions about the appropriate use of the academic ensembles and probably acquiring their own.

\section{Recommendations}

i. Findings point to the fact that the Technical University community is yearning for a customised academic gown. It is therefore, recommended that the university authority should treat their request as very crucial and facilitate the acquisition of the university's own academic ensemble capable to enable wearers stand out distinctly for easy identification and recognition.

ii. Since academic gowns are the official attire for academic ceremonial occasions, every tertiary institution must endeavour to get their customised gowns that can effectively portray the traditions and philosophies of the universities as well as their faculties. In so doing the 'corporate branding' of the tertiary institutions in Ghana will be extending.

\section{Definition of Terms}

In this paper, academic gown refers to academic dress, academic ensemble, academicals, academic costumes, academic robes, and academic garb and are therefore used interchangeably.

\section{Conflict of Interest Statement}

There is no conflict of interest.

\section{References}

[1] Oklahoma State University, Academic regalia/graduation and commencement, commencement.okstate.edu/history-ofacademic-regalia (assessed 24 Aug. 2019).

[2] Cox N., Academical dress in New Zealand, originally published by Burgon Society Annual (2001) pp. 15-24 (20 Aug. 2019).

[3] National University of Ireland. Academic dress of the National University of Ireland. Ireland (2006): available at www.nui.ie > publications > docs > Academic Dress Booklet (assessed 7 September 2019).

[4] Wolgast, S. L., The intercollegiate code of academic costume: an introduction, Transactions of the Burgon Society: Vol. 9. (2009), published by New Prairie Press, 2016: https://doi.org/10.4148/2475-7799.1070 (assessed June 2019).

[5] Wolgast, S. L., A pleasure and an honour': Students' writing on academic dress at Columbia University, 1820-1950, and updates on previous notes, "Transactions of the Burgon Society: Vol. 14 (2014), pp 94-106. https://dx.doi.org/10.4148/24757799.1122 (assessed June 2019).

[6] Report of the committee set up to deliberate and advice on the matter of proliferation of Academic Gowns in the University of Ghana, submitted on the 13th of June 2014. (Unpublished).

[7] Howard P. M. A., Simpson K. B., Peligah Y. S., Assessing wearers' / observers' understanding of the ceremonial significance of academic procession and dress in tertiary institutions: evidence from Kumasi Polytechnic. iiste Arts and Design Studies, Vol. 36, (2015), pp. 5-21.

[8] Osei-Poku, P. Academic robes for University of Science and Technology, Kumasi, Thesis presented to the Board of Graduate Studies, University of Science and Technology for the award of the degree of Ph.D. in Art Education (1999) (Unpublished).

[9] Christianson, B., Academic dress in the University of Hertfordshire. Second edition, revised and extended. Marketing and Communications, University of Hertfordshire. (2006) pp. 1-32, https://uhra.herts.ac.uk > bitstream > handle > Academic Dress Lo-res (https://uhra.herts.ac.uk > bitstream > handle > Academic Dress Lo-res (assessed 20 August 2019).

[10] Fleming, C. A. M., The academical dress of the University of Stirling, 1967-2006, Transactions of the Burgon Society: Vol. 6, No. 5 (2006), pp. 54-76 available at https://doi.org/10.4148/2475-7799.1050 (assessed 2 September 2019).

[11] Sullivan. The Academic Costume Code, Hoods. 
[12] Sullivan, E., History of Academic Regalia, reprinted with permission from 'An academic costume code and an academic ceremony guide,' American Council on Education, American Universities and Colleges, 15th Edition, (C) 1997 Walter de Gruyter, Inc. https://commencement.colostate.edu > history-ofacademic-regalia.

[13] Sullivan. The Academic Costume Code, Gowns, Material.

[14] Sullivan, E., Academic costume code and ceremony guide, American Colleges and Universities, 16th ed., (2001) New York: Walter de Gruyter, Inc.

[15] University of Education, Winneba. Handbook on academic ceremonies, August 2012. Accessed on 5th June 2015 from uew\%20academic\%20ceremonies_new_web\%20\%281\%29.

[16] Rudd, N. A. and S. J. Lennon, Body image and appearancemanagement behaviours in college women, Clothing and Textiles Research Journal, Vol. 18 No. 3, (2000), pp. 152-62 (assessed 22 June 2019).

[17] Roach-Higgins M. E. and J. Eicher, Dress and identity. Clothing and textiles research Journal Vol. 10 (4) (1992) pp. 18. DOI: 10.1177/0887302X9201000401 (assessed 22 June 2019).

[18] Twigg J., Clothing, identity and the embodiment of age. In J. Powell and T. Gilbert (eds) aging and identity: A postmodern dialogue, New York: Nova Science Publishers, (2009) available ww.actyourage.eu/uploads/files/clothing identity and... (assessed 22 June 2019).

[19] Isaac, S., and W. B. Michael, Handbook in research and evaluation: A collection of principles, methods, and strategies useful in the planning, design, and evaluation of studies in education and the behavioural sciences (3rd ed.) (1995). San Diego, CA, US: EdITS Publishers.

[20] Lavrakas, P. J., Cross-sectional survey design. In: encyclopedia of survey research methods (2008) available at: http://dx.doi.org/10.4135/9781412963947.n120 (assessed 13 March, 2019).

[21] Dörnyei, Z., Research methods in applied linguistics. New York: Oxford University Press. (2007) pp. 1-336.

[22] Ahmed, S. (2009), Methods in sample surveys. Simple random sampling, systematic random sampling, Lecture 2. Available at ocw.jhsph.edu. $>$ courses $>$ pdf (assessed 15 June 2019).

[23] Mitra, S. K. and P. K. Pathak, The nature of simple random sampling. The Annals of Statistics Vol. 12 No. 4. (1984), pp. 1536-1542, DOI: 10,124/aos/117634610.

[24] Fraenkel. J. R., N. E. Wallen and H. H. Hyun, How to design and evaluate research in education, New York, McGraw-Hill Higher Education. (8th Ed.). Copyright (C) 2012 pp. 1-710.

[25] Hinton, P. R. (2004), Statistics explained. 2nd edition, pp. 1400, Routledge, London and New York. Available at library.aceondo.net , ebooks , Mathematics, Statistics_Explained-A_Guide. (assessed 7 September 2019).

[26] Hoffmann, N A., Crow's feet and crimson: academic dress at Harvard, Transactions of the Burgon Society: Vol. 9, No. 3 (2009), pp. 38-58, https://doi.org/10.4148/2475-7799.1071 (assessed 2 September 2019). 